\title{
English Oral Communication Apprehension in Students of Indonesian Maritime
}

\author{
Nur Aeni ${ }^{1}$, Baso Jabu ${ }^{1,2}$, Muhammad Asfah Rahman ${ }^{2} \&$ John Evar Strid ${ }^{3}$ \\ ${ }^{1}$ Indonesia Maritime Academy AIPI Makassar, South Sulawesi, Indonesia \\ ${ }^{2}$ State University of Makassar, Makassar, Indonesia \\ ${ }^{3}$ Northern Illinois University, Dekalb, Illinois, USA \\ Correspondence: Nur Aeni, Indonesia Maritime Academy AIPI Makassar, South Sulawesi, Indonesia. E-mail: \\ ainiminollahi@gmail.com
}

Received: March 21, 2017 Accepted: June 5, 2017 Online Published: July 15, 2017

doi:10.5539/ijel.v7n4p158 URL: http://doi.org/10.5539/ijel.v7n4p158

\begin{abstract}
Oral communication is essential for people's workplace performance as well as for university students learning English. Speaking fluently is also crucial for maritime academy students prepared to work in industries abroad. Students need to believe in their ability to speak English. For this reason, sound communication skills are necessary for maritime students so they can compete with seafarer or sailor from other countries. The purpose of this research was to identify the level of oral communication apprehension of nautical students of Akademi Maritim Indonesia (Indonesian Maritime Academy) AIPI Makassar. The sample consisted of 10 first year students at nautical of AMI AIPI Makassar. Data was gathered through questionnaires adapted from Foreign Language Classroom Anxiety Class Scale (FLCAS). The findings indicated that students were generally apprehensive in EFL oral communication. The students showed the highest apprehension for public speaking. The level of nautical students' apprehension based on observation and supported by the modified FLCAS were $20 \%$ in the low category, $60 \%$ in the moderate category, and $20 \%$ in the high category. Students in the high apprehension category showed more symptoms than students in the moderate and low apprehension categories.
\end{abstract}

Keywords: oral communication apprehension, maritime academy, Foreign Language Classroom Anxiety Scale (FLCAS)

\section{Introduction}

In today's global context, a lack of comfort in communicating with others can be an unfortunate inhibitor to success. We sometimes find that many students have difficulty in producing a sentence in English without making mistakes despite their early exposure to the language at schools or university. It also happens to graduates who have problems conversing in English at job interviews. In fact, poor English communication at a job interview in a highly competitive international field might lead to a large number of unemployed graduates in Indonesia. Currently, Indonesia has English study integrated into the curriculum at almost all stages of the educational system. In higher education in Indonesia various fields of study use discipline specific curricula to teach English. For example, in the curriculum in maritime studies, in addition to engineering, courses in English communication were added in the belief that graduates would be joining an international industry in which English will likely be used as a principal means of workplace communication (Maritime Engineering Curriculum, 2011). Graduates in the maritime field need fluent English communication skills in order to succeed in the workplace (Charlesworth, 2008). The maritime industry is particularly important to Indonesia, because of its geographic position as the largest archipelago state in the world, consisting of 17,508 islands from Sabang to Merauke. In addition, the profession of seafarer or sailor in Indonesia is internationally focused, not restricted to one area or country, leading to many multicultural exchanges. Due to the international forums in which seafarers work, they need to be able to speak advanced English, the language of international commerce and exchanges. The President of Indonesia, Jokowi said that he wants to make Indonesia a global maritime axis, (Embassy of the Republic of Indonesia, 2014). President Jokowi has visited Makassar as one of the maritime city in Indonesia. He established a port at Makassar in order to help societies in maritime trading on November 25th, 2016. Accompanied by South Sulawesi Governor Syahrul Yasin Limpo, Makassar Mayor Danny Pamonto, then-coordinator minister for maritime affairs Indroyono Soesilo, and Pelindo IV Director Mulyono, the president gave a speech at Soekarno-Hatta Seaport, translating his national 
maritime vision into a regional roadmap for Makassar. He discussed how improved maritime transportation in the form of a "Tol Laut" or "Sea Toll" would affect the lives of South Sulawesi's citizens, suggesting that if inter-island transportation costs drop, so would the cost of everyday goods. Supporting those goals, the coordinating minister for maritime affairs asserted that the maritime students have to be prepared with English communication skills. Not only the students but the lecturers as well. Sakkir, Rahman, \& Salija (2016) found that the lecturer not difficulties to explain their material for students, so students can explore their argument; make students simply in learning process and easy study; easy communication; the students can train the ability to write with use information that in electronic social media; the students can be free write anything in our mind, spontaneously, and can get much information as well as can get and give critic from another; Some people usually use it for search something important for example, they use it for searching about what is the real purpose of English learning or searching how to improve their language.

Unfortunately, in Indonesia, English still has the status as a foreign language that students rarely use and practice. They speak English only in the classroom. This lack of practice is especially critical for maritime students who will end up working in international contexts while commonly acquiring low abilities in English communication. In fact, the International Maritime Organization (IMO, 2010) identified a problem with the English proficiency of many Asian graduates. Seafarers may lose job opportunities in the global maritime labor market due to their poor English communication ability.

Research demonstrates that various psychological variables affect communication performance. A case in point is the effect that communication apprehension may have on students' overall academic performance (Daly \& McCroskey, 1984). Frymier (2005) also found out that students' communication apprehension affected their learning outcomes. All in all, communication apprehension is a crucial academic success determinant although there could be factors that would be responsible for it. The person with a high level of communication apprehension will avoid talking too much in order to avoid experiencing the fear or anxiety the person has learned to associate with communication encounters (McCroskey, 1977).

Having a fear of making errors or mistakes causes learners to give up some parts of their oral performance. Ellis (2005) stated that having difficulties in oral production is to a high extent the most widespread problem that almost every foreign language speaker experiences during the process of language learning. Compared with other language skills such as reading, writing, and listening, speaking or oral communication is the most apprehension causing skill for language learners. Many speakers experience some apprehension based on a variety of factors. For example, when someone does not feel adequately prepared or otherwise lacks background knowledge about the topic s/he feels really nervous and afraid to talk. Idri, N. (2014) figured out the six causes of communication apprehension are: poor preparation, inappropriate self-expectations, fear of evaluation, excessive focusing on the topic, and fear of the audience's reactions.

This article presents the results of an investigation of maritime academy students' level of communication apprehension. Communication apprehension (CA) is defined as an individual's level of fear or anxiety associated with either real or anticipated communication with another person or persons (McCroskey, 1984). Daly (1985) stated that communication apprehension is the fear or anxiety an individual feels about orally communicating. Most importantly, a number of other related constructs are not directly tied to oral communication, but which nonetheless emphasize people's anxieties about communication. Lucas (2009) found that some level of fear (nervousness) experienced during oral communication is normal for everyone and that it may harm or help communication. Anxiety towards public speaking is very common among both college students and society. About $20 \%-85 \%$ of people experience some anxiety when they need to speak in public (Katz, 2000). The American Psychological Association (2015) defines anxiety as "an emotion characterized by feeling of tension, worried thoughts, and physical changes". Communication apprehension is a type of shyness characterized by fear of or anxiety about communicating with people (Horwitz, Horwitz, \& Cope, 1986). Difficulties in speaking in groups (oral communication anxiety) or in public (stage fright), or in listening or learning a spoken message (receiver anxiety) are all manifestations of communication apprehension. Communication apprehension or some similar reaction obviously plays a crucial role in foreign language anxiety. The students who typically have trouble speaking in groups are likely to experience even greater difficulty speaking in a foreign language class where they have little control of the communicative situation and their performance is constantly monitored (Horwitz, 1991). The difficulties related were irresistible. They spoke of "freezing" in class, standing outside the door trying to summon up enough courage to enter, and going blank when they have a test. They also reported many of the physiological symptoms commonly associated with apprehension (nervousness, trembling, sweating, throbbing, and sleep disturbances). But the researcher focused on some symptoms namely: trembling, getting tense, much of filler or did not say anything. 
Experiences related in support groups contributed to the development of the Foreign Language Classroom Anxiety Scale (FLCAS) (Horwitz, 1983). The scale has demonstrated internal reliability, achieving an alpha coefficient of .93 with all items producing significant corrected item-total scale correlations. Foreign language communication anxiety (FLCA) is defined as "the special communication apprehension saturating foreign language learning [derived] from the personal knowledge that one will almost certainly have difficulty of understanding others and making oneself understood" (Horwitz, Horwitz, \& Cope, 1986). Foreign language apprehension has a critical influence on language learners because they are likely to experience it to a much larger degree than when communicating in their L1. Studies (Daly \& McCroskey, 1984) indicate that students' level of communication apprehension in L1 is significantly lower than their apprehension in L2 (English, in that case).

Moreover, the requirements for communicative competence of seafarers in Standard of Training Certification and Watch keeping of Seafarer (STCW, 2010) presented great challenges to Indonesian seafarers who need to improve their English communication ability. The language problem in Indonesia is mainly attributable to improper maritime English education and training in Indonesia. Most class time is spent giving lectures that focus on explaining vocabulary and grammar, leaving little time for individual and group interactions. In class, teachers generally expect students to say grammatically correct English. In fact, teachers commonly put pressure on students to produce perfect sentences when speaking. The consequence may be hesitancy, fear, and anxiety when using the language in real communicative contexts. The degree of communication apprehension of Indonesian maritime students has never been completely examined, meaning that research examining their level of English communication anxiety would help assess if and how Indonesian English teacher competencies, teaching methods, and instructional materials should be changed.

This study aims at answering the following question:

What is the maritime academy AIPI Makassar students' level of communication apprehension during an oral communication task (speaking test)?

\section{Method}

This research investigates the level of students' communication apprehension at Maritime Academy AIPI Makassar and uses a mixed method approach. One quantitative and qualitative method the researcher used to collect data was to administer a questionnaire to measure the degree of apprehension felt by first year nautical students during oral communication. The questionnaire was adapted from Foreign Language Classroom Anxiety Scale (Horwitz, 1987), changing some wording and selecting the most relevant questions to examine communication apprehension. The version used during this study consisted of twenty-five questions with responses given on a five point Likert-scale, with the scale ranging from strongly agree to strongly disagree. This questionnaire was adapted to investigate specifically maritime students' extent of apprehension when forced to communicate orally in their English class, choosing items from the original survey most appropriate to students at the Maritime Academy and translating them into Indonesian and rewording in some cases. All of the questions were chosen to indicate if students feel anxious or apprehensive in speaking English as foreign language. All the statements in the questionnaire are presented to all participants in both Indonesian and English in order to avoid possible misinterpretation for the students. Some example statements from the questionnaire include:

I tremble when I know that I am going to be called on during a speaking test;

I start to panic when I have to speak without good preparation;

At the time of a speaking test, I feel very nervous when I forget what to say;

Although I have already prepared my speaking test or presentation very well, Istill feel anxious;

I feel my heart beat faster when I start the speaking test;

Sometimes I feel do not want to face presentations or speaking test;

I am worried if the teacher/lecturer corrects the mistakes I make during the speaking test;

The more I prepare myself for the speaking test, the more I feel anxious;

I feel more nervous and anxious when faced with a speaking test than a written test;

I am afraid if people laugh when I have my speaking test by using the English language;

It frightens me when I do not understand what the lecturer is saying in the foreign language.

The questionnaire was administered at the end of the semester with the students filling out the questionnaire in one class meeting using approximate thirty of the ninety minute class duration. It was distributed to a class of 15 nautical 
students in the session prior to a speaking test, but only 10 of the students returned the questionnaire within a day. The data collected from the questionnaire was analyzed both quantitatively and qualitatively and was supported by observation. The observation was held in the next class when the students were having the speaking test. The speaking test was a test that the researcher designed every semester in order to know whether the students of maritime academy could produce English. This is a part of the speaking test that the researcher used.

Mini Presentation (2-3 minutes)

In this part of test, you are going to talk on your own. I am going to ask each of you a question, and I'd like you talk about your answer in a minute. You have 30 seconds to prepare your answer.

(Repeat the instruction to the students)

(Choose one topic below to be asked to the students. Remember, one question for one student only)

a. In your opinion, what is the best ship for you in the future? Why?

b. What is communication? Tell me!

c. Do you think doing sport is important? Why?

When the speaking test was held, the researcher observed the students looking for examples of characteristics based found in the adapted version of the FLCAS questionnaire. Specifically, the researcher was monitory if the students trembled, if they repeated the same words two or three times, if they spoke too slowly or quickly, if they had many fillers like "uuuh" or if they had a deadpan expression.

\section{Participants}

The participants of the study were 10 students from the Nautical department at AMI AIPI Makassar. The students from this department work as on board captains or other deck officers. The deck officers have responsibility to ensure continuous smooth operations on any seagoing craft. Nautical department students were chosen as participants because they are preparing to working in international trade and their responsibilities when they are on a ship are harder than others. The participants' ages range from 16 to 21 (with an average age of) and included eight male students and two female students.

These students were taking the course "General English I" during 2015-2016 and the questionnaire was administered at the end of the course. General English I is an extended course that maritime academy students have to take as a part of the sequence during the first semester in their first year of study. The students had studied English as a foreign language since their junior year in high school. However, their level of English fluency was variable, ranging from basic to proficient. The English class in first year focuses on language used for talking about daily life and general language knowledge. The class' objectives are for students to be able to communicate and produce oral communication proficiently. In this course, the students need to be able to show sufficient comprehension of simple grammar, use appropriate vocabulary to talk about everyday situations, perform simple exchanges, and produce responses which are extended beyond short phrases. These participants were appropriate to examine the research question of this study because their range in English proficiency could potentially contribute to some degree of apprehension during English communication.

\section{Results}

This section examines the results of the questionnaire and their implications. The findings follow the research problem outlined in the introduction section. The researcher shares results from each participant including a measure of each student's level of anxiety obtained through modified FLCAS (Foreign Language Class Anxiety Scale). In the discussion section, arguments and further interpretation of the findings are given.

\section{Level of oral communication apprehension in Nautical students at AMI AIPI Makassar.}

The modified FLCAS questionnaire was used to investigate whether the students were in a high, moderate, or low apprehension category. After the participants filled out the questionnaires, the researcher then scored them marking the rating for each question from each partipant. After examining each participant's FLCAS questionnaire, the answers to all questions were compiled to create an overall apprehension rating, using the Likert Scale outlined in Table 1 to score survey questions according to whether they were positive or negative. The data were calculated manually with scores possibly ranging from 25 to 125 . After obtaining a composite score from each student's FLCAS results, it was categorized into a level of apprehension: high (90-125), moderate (67-89), or low (25-66). Table 2 gives the range of scores for each degree of apprehension. The results showing the numbers of students and percentages at the different levels of apprehension based on the modified 
FLCAS questionnaire can be viewed in table 3 below. The questionnaire results were also used to inform observations of the students' level of apprehension during a later oral communication task.

Table 1. Adapted from the Likert scale

\begin{tabular}{llllll}
\hline & \multicolumn{4}{c}{ Scoring } \\
\cline { 3 - 5 } Statement & Strongly Agree & \multicolumn{2}{c}{ Agree Undediced Disagre } & Undecide DiStrongly disagree \\
\hline Positive & 1 & 2 & 3 & 4 & 5 \\
Negative & 5 & 4 & 3 & 2 & 1 \\
\hline
\end{tabular}

Table 2. Horwitz, E. K., Horwitz, M. B., \& Cope, J. (1986)

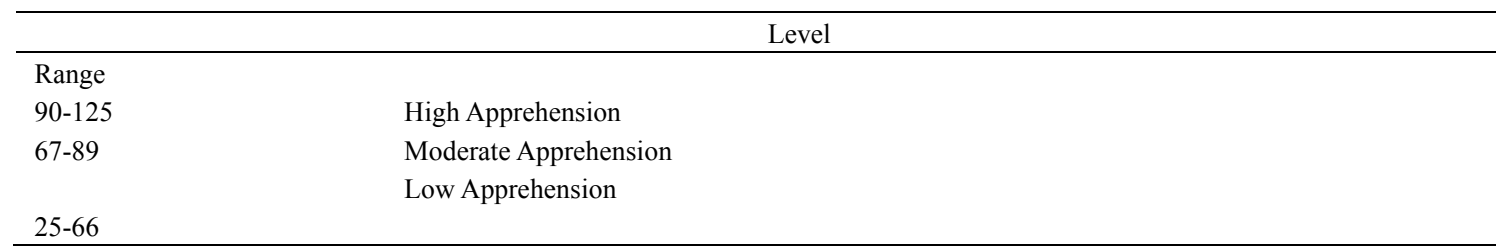

Table 3. The percentage level of students' apprehension

\begin{tabular}{lll}
\hline Level of Apprehension & Number of students & Percentage \\
\hline Low & 2 & $20 \%$ \\
Moderate & 6 & $60 \%$ \\
High & 2 & $20 \%$ \\
\hline
\end{tabular}

\section{Discussion}

\section{a. Participant 1}

The score on the FLCAS of participant 1 was 83 out of a possible score 125. This result indicates that participant 1 had moderate apprehension. Participant 1 stated that she felt less apprehensive in speaking in public. Based on the observation of participant 1 , she did in fact experience moderate communication apprehension while completing the communication activity. When her name was called to take the speaking test, she smiled and before she started, she took a long breath. During the test, she did not look very anxious and her voice was normal although sometimes she forgot what to say.

\section{b. Participant 2}

Participant 2's score on the FLCAS was 69 out of a possible 125. This result indicated that participant 2 had moderate anxiety. The data from his observation sheet supported these findings. This result indicated that participant 2 had lower anxiety than participant 1 . Participant 2 stated that he did not feel very anxious in the speaking test. During the first minutes of the speaking test, his face looked twitchy and his voice was rather trembling. But after about two minutes, he apparently was able to take control of himself and manage his anxiety. After the first two minutes, his voice became normal. Although sometimes he searched for words, his tone did not indicate that he was nervous and she breathed normally.

\section{c. Participant 3}

The score on the FLCAS of participant 3 was 66 out of a possible 125. This result indicated that participant 3 had low anxiety. Participant 3 stated that he felt less anxiety in speaking in public. Participant 3 also did not seem very nervous before the speaking test was held. His English was good. Both his pronunciation and vocabulary were good, and his grammar was also not too poor, even though he occasionally repeated a word about two or three times. He did not have a deadpan expression.

\section{d. Participant 4}

Participant 4 had a score on the FLCAS of 76 out of a possible 125. This result indicated that participant 4 had moderate anxiety. Participant 4 stated that she felt anxious in speaking in public. She smiled and walked into the class confidently when her name was called to have the speaking test. Unfortunately, when she started the speaking test she became nervous, affecting her test. Her voice trembled, she spoke too fast, and she had a deadpan expression. During the speaking test, she spoke hesitantly and with too many "uhhh"or filler words. In addition, she frequently repeated words about two or three times. She looked like she was in doubt about word 
choice. The researcher also noticed some mispronunciations. In general, the participant looked apprehensive, breathed heavily, and waved her hand frequently.

\section{e. Participant 5}

Participant 5 needed to complete the speaking test a second time, since his first attempt was stopped because of poor performance. His score on the FLCAS was 70 out of a possible 125, indicating moderate anxiety. This finding was further supported by data from his observation. During his first attempt on the speaking test, participant 5 stated that he felt anxiety. During this test, he consistently forgot what to say, had too many pauses, mumbled, and used fillers "uhhh..." Because of the participants' performance was not good, the lecturer gave him a second chance. Participant 5 did not seem well prepared since he continually read from notes during the test. However, on his second try he no longer felt that anxiety disturbed him and his performance was better than before. He did not read his notes anymore. During the speaking test, he looked more confident although he still mumbled a lot ("uhhh....") during his speech.

\section{f. Participant 6}

Score on the FLCAS of Participant 6 was 64 out of a possible 125. This result indicated that Participant 6 was in the category of low apprehensive. However, according to researcher's observation participant 6 stated that he felt nervous in interviewing and public speaking. Before Participant 6 performed the speaking test, the researcher watched him walked back and forth in the room, talked with her friend, even with the researcher and she said that: "I am really nervous, sister, what should I do to reduce my anxiety? My body is cold and I am shaking." But then, when the speaking test started, he looked very calm. He started his speaking test with a full smile on her face. When he introduced himself, he looked a little bit nervous but it did not take a long time before he could control herself and speak like a professional speaker. Although he made too many body movements, it did not indicate that he had high apprehension.

\section{g. Participant 7}

Score on the FLCAS of participant 7 was 90 out of a possible 125. This result indicated that participant 7 had high anxiety. Participant 7 stated that she felt very anxious when speaking in public. During the first performance, she looked very nervous. Her face looked very worried and her face muscles were tense. There were awkward pauses (mumble "uhhh...."), stammering and halting, and her speech seemed blocked. She often repeated the same word. There were, also many mispronunciations and she lacked vocabulary. She had a deadpan expression. These symptoms indicated that she was very anxious.

\section{h. Participant 8}

Participant 8 was 68 out of a possible 125 based on FLCAS. This result indicated that participant 8 was in the category of moderate apprehensive. Participant 8 stated that he did not feel very anxious about speaking in public. He spoke slowly but the researcher still understood what the participant said. He felt nervous and had many body movements like shaking his hands.

\section{i. Participant 9}

Score on the FLCAS of participant 9 was 92 out of a possible 125. This result indicated that participant 9 had high apprehension. Participant 9 stated that he felt very apprehensive about speaking in public. Based on the observation of the first performance, her voice quivered. He stammered and halted and awkward pauses were made. He made some grammatical mistakes, mispronunciations, and lacked vocabularies. He also repeated one word many times. He showed discomfort with her body movement and used too many fillers.

\section{j. Participant 10}

Score on the FLCAS of participant 10 was 71 out of a possible125. This result indicated that participant 10 was in the moderate apprehensive range. When participant 10 performed his speaking test, he had a deadpan expression, without a smile. He paused and did not say anything for 2 or 3 minutes.

During the observation, some students had to repeat their speech because their performance did not run well. Based on the result of the questionnaire and observations, there were two participants who were indicated to be low apprehensive, supported by FLCAS results. They experienced the symptoms of apprehension only at the first time they spoke, then they could manage and control their communication in order to get a good performance. Ortega (2009) states that foreign language speaking anxiety includes many symptoms such as freezing up and getting confused in spite of having studied hard. Hanna \& Gibson (1987) provide that public speaking anxiety is manifested in many ways (i.e., blood pressure, hand trembling, weakness in some parts of the body, feeling anxious, forgetting the prepared material, and avoiding looking at the audience). Moreover, the 
results indicated that six participants had moderate apprehension. They still showed the symptoms of apprehension such as mumbling, many fillers, and flat expression. Although they looked very anxious at the beginning of the speaking test, they still tried to cope their apprehension by using techniques such as: deep breathing, smiling, and using hand gestures. There were two participants who were indicated to have high apprehension. During the speaking test, they were nervous, used many fillers, and sometimes they did not speak at all.

Amogne \& Yigzaw (2013) indicated that apprehension profoundly affects how people communicate, and communication is critical to success in academic settings as well as virtually all other environments. The researcher believed that the students felt anxiety or apprehension because they did not practice their English conversation enough. In this case, the students did not have much time to practice their English, only ninety minutes a week. The researcher also believed that the students were worried about their evaluation. Idri (2014) believes that fear of negative evaluation is also another inhibitor of oral communication apprehension. Most of participants felt apprehensive because they knew that the speaking test was the final test that the lecturer evaluated their progress.

Lack of an extensive vocabulary in English is a crucial factor in oral communication apprehension. When people are speaking without background knowledge or vocabulary related to the topic, she/he feel reluctant to speak and it reveal communication apprehension. Yahya (2013) found that having oral communication without good preparation and extension vocabulary can lead someone to be anxious and more apprehensive.

Based on those explanation, the researcher constructed that the more symptoms of anxiety that the students have, the more anxious or apprehensive they are. In contrast, the fewer symptoms they have, the less anxious or apprehensive they will be.

\section{Conclusion}

Based on the FLCAS, the research findings and discussions in the previous section, the researcher concluded that the level of students' apprehension at Maritime Academy AIPI Makassar during the speaking test was as follows: students categorized with high apprehension was $20 \%$, students categorized with moderate apprehension was $60 \%$, and the students categorized with low apprehension was $20 \%$. Students' anxiety seemed to be a crucial problem. The students experienced apprehension, worry, even dread. They had difficulty concentrating, became forgetful, sweat and trembled. They sometimes did not speak at all. Students felt anxious due to lack of practice, insufficient vocabulary, and fear of negative evaluation. However, teachers cannot guarantee that a class will be anxiety-free. Teachers should be aware of trying to minimize the anxiety in the classroom to strengthen language learning efficiency and can use techniques such as warm up activities, group work, and conversation practice to foster the students' confidence.

\section{Recommendation}

Since the level of students' communication apprehension at AMI AIPI Makassar indicated the majority of the students exhibited moderate to high apprehension, the lecturers need to be more creative about establishing a cheerful atmosphere in the language classroom because the mood dimension is a factor in oral communication apprehension. In a state of positive mood, learners are less likely to experience apprehension. Teacher should help their students to mitigate their apprehension by providing some interesting activities in the classroom. For further research, finding empirical evidence concerning how effective anxiety reducing techniques are in foreign language classrooms is suggested.

\section{Acknowledgments}

The researcher addresses thanks to Direktorat Kualifikasi Sumber Daya Manusia, KEMRISTEK DIKTI (Ministry of Research, Technology and Higher Education of Indonesia for the financial support (PKPI Program 2016), State University of Makassar, Northern Illinois University and AMI AIPI Makassar.

Special thanks to the researcher's mentor at Northern Illinois University (NIU), John Evar Strid, PhD who has given advice and great contribution in accomplishing this article.

\section{References}

American psychological association. (2015). Anxiety. Retrieved from www.apa.org/topics/anxiety/

Amogne, D., \& Yigzaw, A. (2013). Oral communication apprehension, competence and performance among maritime engineering trainees. Journal of Media and Communication Studies, 5(1), 5.

BDU. (2011). Maritime Engineering Curriculum. Retrieved from http.scienceedu.com 
Bennett, K., \& Rhodes, S. C. (1988). Writing apprehension and writing intensity in business and industry. Journal of Business Communication, 25(1), 25-39. https://doi.org/10.1177/002194368802500102

Carruthers, A. M. (2015). Developing Indonesia's Maritime Infrastructure: The View from Makassar.

Charlesworth, D. (2008). Identifying Communication Apprehension Levels in Upper-Level Information Systems Majors: A Pilot Study.

Colleen, C. M., \& Matthew, M. M. (2011). Instructors' Perceptions of Teaching Behaviors, Communication Apprehension, and Student Nonverbal Responsiveness in the Classroom. Communication Research Reports, 28(2), 141-150. http://dx.doi.org/10.1080/08824096.2011.5652

Croucher, S. M. (2015). A Cross-Cultural Analysis of Communication Apprehension. Journal of Intercultural Communication, 38. Retrieved from http://immi.se/intercultural

Daly, J. A., \& McCroskey, J. C. (1984). The Communication Apprehension Perspective. In Avoiding Communication: Shyness, Reticence, and Communication Apprehension. London: Beverly Hills: Sage Publications Ltd.

Diamar, S. (2015). Lima Pilar Membangun Poros Maritim Dunia. Jurnal Maritim. Retrieved from jurnalmaritim.com/2015/03/lima-pilar-membangun-porosmaritim-dunia

Embassy of the Republic of Indonesia. (2014). Indonesian archipelago. Retrieved from http://www.indonesia.hu/page.php?id=99\&titlethearchipelago

Fan, L., Fei, J., Schriever, U., \& Fan, S. (2015). Communication challenges to maritime English education and training in China in the modern shipping world. In 2015 Master Mariners Congress (pp. 1-10).

Frymier, A. B. (2005). Students' classroom communication effectiveness. Communication Quarterly, 53(2), 197-212. https://doi.org/10.1080/01463370500089896

Hanna, M. S., \& Gibson, J. W. (1991). Public speaking for personal success. William C. Brown.

Horwitz, E. K. et al. (1991). Language Anxiety: From Theory and to Classroom Implications. Englewood Cliffs: Prentice-Hall, Inc.

Horwitz, E. K., Horwitz, M. B., \& Cope, J. (1986). Foreign language classroom anxiety. The Modern Language Journal, 70(2), 125-132. https://doi.org/10.1111/j.1540-4781.1986.tb05256.x

Idri, N. (2014). Fear of Negative Evaluation as a Variety of Anxiety in Foreign (Doctoral dissertation, Bejaia University).

Jones, R. A. S. (1997). Is there still a chill? Student perceptions of gender bias in the college classroom. (Doctoral dissertation).

Leary, M. R. (2013). Social Anxiety, Shyness, and Measures of Personality and Social Psychological Attitudes. Measures of Social Psychological Attitudes, 1, 161.

Leary, M. R. et al. (1991). Social anxiety, shyness and related constructs. Measures of Personality and Social Psychological Attitudes. San Diego, DA: Academic Press.

Lucas, S. (2009). The Art of Public Speaking. USA: McGraw Hill Education.

McCroskey, J. C. (1977). Oral Communication Apprehension: A Summary of Recent Theory and Research. Human Commun. Res, 4(1). McIntyre PD, Baker.

Ortega, L. (2009). Understanding second language acquisition. New York: Routledge.

Rojo-Laurilla, M. A. (2007). Communication apprehension and communicative competence among maritime students in the Philippines. Journal of Reflections on English Language Teaching, 6(2), 39-58.

Sakkir, G., Rahman, A., \& Salija, K. (2016). Students' perception on social media in writing class at Stkip Muhammadiyah Rappang, Indonesia. International Journal of English Linguistics, 6(3), 170-175.

Yahya, M. (2013). Measuring speaking anxiety among speech communication course students at the Arab American University of Jenin (AAUJ). European Social Sciences Research Journal, 1(3), 229-248.

\section{Copyrights}

Copyright for this article is retained by the author(s), with first publication rights granted to the journal.

This is an open-access article distributed under the terms and conditions of the Creative Commons Attribution license (http://creativecommons.org/licenses/by/4.0/). 